\title{
JOB SATISFACTION AS A MEDIATOR OF JUSTICE TOWARDS ORGANIZATIONAL CITIZENSHIP BEHAVIOR
}

\author{
Alfato Yusnar Kharismasyah*, Bima Cinintya Pratama, Fatmah Bagis \\ University Muhammadiyah Of Purwokerto \\ *email: chipatoyusnar@gmail.com
}

\begin{abstract}
Abstrak: Waktu berjalan dan kompetisi semakin ketat. Hal ini menuntut para karyawan untuk menunjukkan kinerja terbaiknya agar mampu melampaui standar kerja yang ditetapkan perusahaan. Inovasi sistem kerja di perusahaan perbankan memberi stimuli bagi para pekerja mulai dari tingkat dasar hingga tingkat manajemen untuk selalu aktif dan memahami deskripsi kerjanya. Extra ordinary behaviour, yang kerap disebut organizational citizenship behaviour menghasilkan anggapan yang menyatakan bahwa karyawan hendaknya tidak hanya menguasai satu keahlian saja, tapi lebih dari satu keahlian di luar deskripsi pekerjaan mereka. Untuk itu, tujuan studi ini adalah untuk menganalisis pengaruh distributive dan procedural justice pada OCB melalui kepuasan kerja. Penelitian ini berformat deskriptif dan verifikatif. Penelitian deskriptif digunakan untuk memperoleh deskripsi distributive justice, procedural justice, job satisfaction dan OCB. Riset verifikatif dilakukan untuk mengetahui hubungan Antara variabel - variabel dengan menggunakan perhitungan statistik. Metode yang digunakan adalah metode survey. Sedangkan teknik pengambilan sampelnya adalah saturated / census samples dengan jumlah 65 responden. Analisis data di studi ini menggunakan metode PLS dan menemukan bahwa distributive justice dan procedural justice memiliki pengaruh signifikan terhadap kepuasan kerja yang mempengaruhi OCB. Terdapat beberapa peneliti yang meninjau OCB dari sudut pandang sumber daya manusia. Riset ini diharapkan dapat membantu para manajer untuk memformulasikan strategi dan implementasi kebijakan terkait dengan sumber daya manusia yang diperlukan dan menciptakan sumber daya manusia yang baru dengan segala kemampuannya untuk mampu melakukan peran tambahan.
\end{abstract}

\begin{abstract}
Time goes rapidly and competition is getting tougher. It demands employees to give high performance in order to exceed work standard determined by the company. Work system innovation in banking companies provide stimuli for employees both from lower-rank employees to management level to always be active in and have advantages in understanding the job desk. Extra ordinary behavior, which is usually called Organizational Citizenship Behavior, is expected to change mindset where employees do not only master one ability, but several abilities or skills beyond their job description. Therefore, the purpose of this study is to analyze the influence of Distributive and Procedural Justice on OCB through Job satisfaction. This research is descriptive and verificative. The descriptive research was conducted to obtain a description of Distributive Justice, Procedural Justice, Job satisfaction, and OCB. Verificative research is done to know the relationship between variables through statistical calculation. The method used is survey method. The sampling technique is Saturated / Census Samples with 65 respondents. The data analysis used in this study is the analysis of PLS (Partial Least Square) and found that the Distributive Justice and Procedural Justice have significant influence on Job Satisfaction that impact on OCB. There are several researchers who have researched $O C B$ from human resource point of view. The contribution of this research is to help managers to formulate strategies and policy implementation related to the proper management of Human Resources and create new Human Resources with all the best ability to play an extra role in doing the job.
\end{abstract}

Keywords: OCB, Job Satisfaction, Justice

\section{INTRODUCTION}

Organizational Citizenship Behavior (OCB) is a crusial factor for the efficiency of the organization, effectiveness, innovation and ability to adapt in various organizations (Organ, 1988; Rifai, 2005). The relationship of Organizational Citizenship Behavior will possibly be influenced by the relationship between organizational justice (distributive justice, procedural justice), so the role of organizational justice will have an impact on Organizational Citizenship Behavior (Rifai, 2005). Banking company, Bank Negara 
Indonesia, is one of state-owned enterprises (BUMN) that is now in transition period both the operational system and human resources in order to achieve maximal performance, especially the human resources who are pushed to work more than the job description. Organizational Citizenship Behavior (OCB) is not a formal work obligation for an employee, but it supports the effective functioning of the organization. Many successful organizations need employees who will act beyond their general job duties that will perform well (Robbins, 2006). therefore, Organizational Citizenship Behavior in an organization has an important role for the organization to perform its activities effectively and efficiently.

The ability and willingness of a person to do a job outside of his or her job desk is closely related to the company's justice towards its employees, here it is clear that fair management policies in making decisions related to career, wage and benefits issues have a major impact on OCB, so knowledge of distributive justice and Procedural Justice can help managers to be fair in distributing financial rewards and promotions (Kreitner and Kinicki, 2003). Research conducted by Baker et al. (2006) investigated about OCB influenced by Distributive Justice and Procedural Justice. The result of this research suggests that the relationship of Distributive Justice and Procedural Justice against OCB was not too significant, therefore it should be noted in any further. OCB can arise from various factors in the organization, among them due to employee job satisfaction and high organizational commitment (Robbin and Judge, 2007), employees who get justice in their companies will feel satisfied and are more likely to speak positively about the organization, help co-workers, and make their performance beyond the normal estimate of the company where it is closely related to OCB.

From the explanation, problem statement can be made that there was limitedness on the research conducted by Baker et al (2006) which studied about the influence of Distributive Justice and Procedural Justice against OCB, and suggested to add Job Satisfaction as a mediator.So, this study contributes is developing research Baker et al. (2006), then this study formulates the issue as follows:
1. How is the effect of Distributive Justice on Job Satisfaction?

2. How is the effect of Procedural Justice on Job Satisfaction?

3. How is the effect of Job Satisfaction as a mediator between Distributive Justice and Procedural Justice on OCB

The next section of this paper will discuss about literature review, method of the research, result, discussion, conclusion, and implication of business or management that can be taken from this research.

\section{LITERATURE REVIEW AND HYPOTHESIS DEVELOPMENT}

\section{Organizational Citizenship Behavior \\ 1. Definition of Organizational Citizenship Behavior (OCB)}

Freund (2003) defines that Organizational Citizenship Behavior (OCB) is a behavior that exceeds the functions and tasks assigned formally to employees of an organization. Such behavior is very necessary because it will contribute to better organizational performance. The primary concern about OCB is that this behavior can increase the organizational functions and even to make the organization more effective because the behavior of the employee is not clearly described in the job description. The original concept of OCB in general is regarded to extra-role behavior (Bienstock, et al. 2003).

\section{Dimensions of Organizational Citizenship Behavior (OCB)}

Many researchers outline the dimensions Organizational Citizenship Behavior (OCB). Organ (in Diefendorff et al., 2002) outlines the five dimensions of Organizational Citizenship Behavior (OCB), namely:

a. Altruism, is a willingness to give help to others

b. Civic Virtue, members give contribution on the political issues in the organization in a responsible manner.

c. Conscientiousness that members are discipline in time, have high percentage of attendance, and perform more than normal needs and expectation.

d. Courtesy, is kind and respect to others, 
including such behaviors as helping someone prevent a problem and making strategic steps in order to soothe/reduce a problem.

e. Sportsmanship, is a behavior that emphasizes positive aspects of organization rather than the negative aspects, indicates a behavior that is not pleased with process, does not complain, and does not exaggerate small problem.

\section{Job Satisfaction}

Locke (1976) argues that job satisfaction is the phenomenon of psychology and is a function of individual's expectation to achieve and obtain something from the work. In addition, "satisfaction" is also an individual extensive feeling. The extent of the feelings is obtained from each individual comparison between reality and hope. If the situation that happens is an awareness of individual expectation not being achieved, the greater the gap that is formed, the bigger the disappointment is also possibly happening. Conversely, if the hope is achieved or exceeded, the intended party will be satisfied. Therefore, the level of satisfaction is influenced by the size of the gap between the observations and expectations.

Ivancevich (1987:64) gives definition of job satisfaction as follows: job satisfaction is a person's attitude towards their work. The attitude comes from his/her perception about his/her work. Of the various factors above five important factors are:

f. Compensation: financial return that is received and felt

g. Job: a condition where a job is seen to be interesting, gives a chance to learn, and to be responsible.

h. Chance of promotion: an opportunity to go further

i. Supervision: supervising ability to show interest and concern to the members

j. Relationship of partnership: a condition where a partner shows friendly and supportive manners

\section{Procedural Justice}

Procedural justice is defined as justice that is felt from the process and procedure used to allocate decision (Kreitner and Kinicki, 2003). A condition of a job that is relevant with employee's personality will encourage him/her to work more maximally because s/he feels comfortable with his/her job.

Justice in providing work procedure and work status puts forward how employees get justice where their performance is directly proportional with the carrier achievement (Rifai, 2005) and work achievement is a dominant element of procedural justice. Here are the assessment levels of Procedural Justice: a. Assessment of work achievement consistent with work realization

b. Justice of work achievement assessment

c. Accuracy of work achievement evaluation

d. Errors in work achievement assessment

\section{Distributive Justice}

Kreitner and Kinicki (2003) define distributive justice as a justice that is felt on how resources and rewards are distributed or allocated. Distributive justice is highly related to employees' wage. Organization that is willing to realize its employees' satisfaction should be able to meet pay equity, as suggested by Carraher et al (1992); Tremblay, M. et al (2000) that such employee benefit equity as pay equity can influence satisfaction with compensation. Here are the indicators of Distributive Justice:

a. Compensation is relevant with contribution to organization.

b. Compensation is relevant with responsibility

c. Compensation is relevant with education level and training

d. Compensation is relevant with work achievement

e. Compensation is relevant with work risk

\section{Hypothesis Development}

Rifai (2005) suggests that both distributive justice and procedural justice have effect on job satisfaction and evaluation from supervisor. Their research also found that distributive justice has significant effect on loyalty to organization and job satisfaction. Folger and Konovsky (1989) have examined employee reactions to payment systems, finding that distributive justice acts as the strongest predictor of job satisfaction on wages rather than procedural justice. Davis and Ward(1995); Trembly, M. et al (1998), found evidence that employees' perceptions of distributive justice were important predictors of job satisfaction, 
and Martin and Bennett (1996); Trembly, M. et al (1998) saw a significant causal relationship between distributive justice and job satisfaction. Besides that, Pareke et al (2003) in his research suggests that Job Satisfaction is a mediating variable of correlation between distributive and procedural justice againts OCB. In Cyprus, Nadiri and Tanova (2010) investigated the effect of organizational justice perceptions (distributive, procedural, and interactional justice) of hotel employees with job satisfaction, $\mathrm{OCB}$, and turnover intention. Their study found that distributive justice was the stronger predictor of all various work related variables (job satisfaction, $\mathrm{OCB}$, and turnover intention) than procedural justice.

Hypothesis 1: Distributive justice has effect on job satisfaction.

Rifai (2005) said that several procedural factors are likely to correlate with job satisfaction. Those factors, including freedom to make decision related to job, give contribution to the organization process. Alexander and Ruderman (1987) prove the relationship between procedural and distributive justice factors and six organizational variables, including job satisfaction, evaluation of supervisor, conflict-harmony, turnover intention, trust in management, and tension-stress, they confirm that procedural fairness is associated with low conflicts and disharmony within the organization. This is in accordance with the statements of Folger and Konovsky (1989); Rifai (2005) which states that employees will reflect negative attitudes and behavior as a form of grievance dissatisfaction if the explanation of decision-making procedures is not appropriate in their perception. Tremblay (2000) in his research also found that in employee benefit satisfaction: perceived procedural justice is a better predictor than in distributive justice.

Hypothesis 2: Procedural justice has effect on job satisfaction.

OCB can arise from various factors in organization, among others are due to employee's work satisfaction and high organization commitment (Robbin, 2006). When employees feel satisfied with their work, the employee will work optimally to complete his work, even doing some things outside his job desk (Robbin and Judge, 2007). The result of the research (Bateman \& Organ, 1983; Smith, Organ \& Near, 1983; Organ, 1988b; Organ \& Ryan, 1995) depicts that there is consistency of positive relationship between job satisfaction and OCB. Job satisfaction can influence turnover level and absence level in reverse (Greenberg and Baron, 2008). The higher the level of employee's job satisfaction will decrease the turnover level and employee's absence. Meanwhile, performance level and OCB have directly proportional relationship i.e. the higher the Job Satisfaction will increase employee's performance and OCB. Many researchers have indicated that there are many factors that can affect organizational citizenship behaviors and turnover intention. They have suggested that organizations offering better and improved organizational justice are more likely to succeed in attracting and retaining valuable staff (Abu Elanain, 2010a; Ince \& Gül, 2011; Lambert et al., 2010). The reason is that organizational justice is associated with organizational commitment (Azeem, 2010), employee job satisfaction, and organizational citizenship behaviors (Olkkonen \& Lipponen, 2006). The use of organizational justice for promoting organizational citizenship behaviors is a relatively late research interest, even though an extensive amount of empirical research has already been investigated in this area. According to Organ (1990), justice perceptions have a main role in promoting organizational citizenship behaviors. According to Organ (1990), performing employees organizational citizenship behaviors are a response to fair treatment offered by an organization. This is because when employees perceive their working atmosphere is fair, this increases their job satisfaction and in turn prompts them to perform citizenship behavior (Moorman, 1991).

Hypothesis 3: Job Satisfaction can mediate between Distributive Justice and Procedural Justice on OCB 
Based on the hypothesis that has been be studied in this research is shown in the explained earlier, the research model that will following figure:

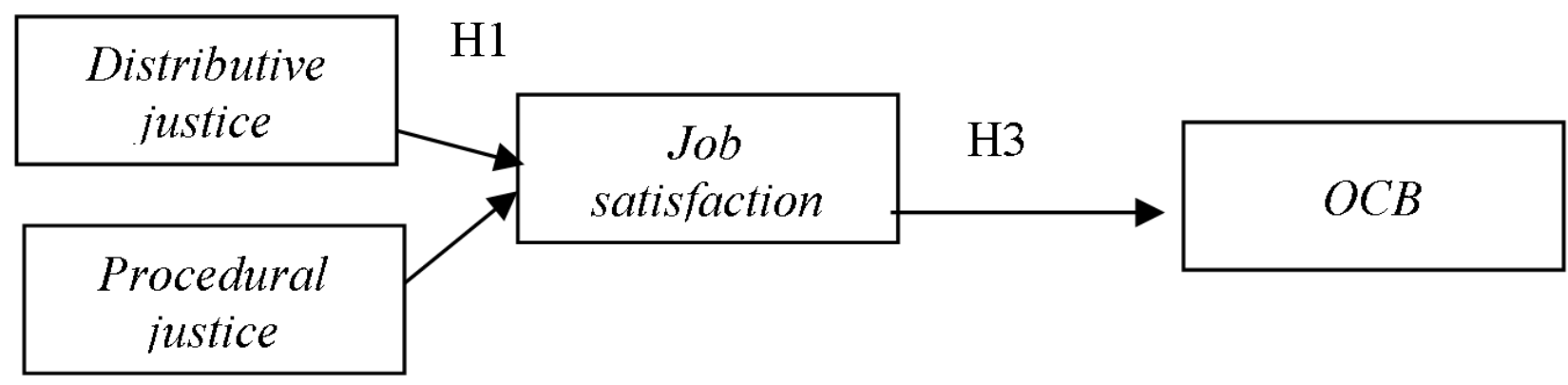

$\mathrm{H} 2$

\section{Research Framework}

\section{RESEARCH METHOD}

\section{Type of the Research}

It belongs to survey research. Survey research is used to clarify the causal relationship among variables through hypothesis testing (Singarimbun and Effendi,1995).

\section{Type and Source of Data}

The data used in this research were primary data. Primary data are original data collected by a researcher to answer research problem (Istijanto, 2005).

\section{Method for Collecting Data}

Questionnaire is a technique for collecting data by administering questions to respondents in order for them to give response for those questions (Umar, 2000). The questions of the questionnaire in this research were asked to know respondents' response against variable distributive justice, procedural justice, job satisfaction, and OCB.

\section{Sample}

The sampling technique used in this research was saturation sampling (census). Saturation sampling is when all population members are used as the sample (Sugiyono, 2003: 61). The researcher used this method because the numbers of the employees of PT. Bank BNI (Persero) Kebumen Branch were 65 persons (less than 100).

\section{Definition and Measurement of Research Variables and Indicators}

Table 1. Conceptual and Operational of Variables

\begin{tabular}{|c|c|c|}
\hline Variable & Conceptual and Operational Definition & Indicators \\
\hline (1) & (3) & (4) \\
\hline $\begin{array}{l}\text { Distributive } \\
\text { justice }\end{array}$ & $\begin{array}{l}\text { Conceptual: } \\
\text { Justice that is felt regarding with how } \\
\text { resources and rewards are distributed and } \\
\text { allocated (Kreitner and Kinicki, 2003). } \\
\text { Operational: } \\
\text { Perception of the employees of BNI } \\
\text { Branch Kebumen about rewards } \\
\text { and compensation received from the } \\
\text { organization }\end{array}$ & $\begin{array}{l}\text { 1. Compensation relevant } \\
\text { with the contribution to } \\
\text { organization. } \\
\text { 2. Compensation relevant } \\
\text { with responsibility } \\
\text { 3. Compensation is relevant } \\
\text { with education level and } \\
\text { training. } \\
\text { 4. Compensation is relevant } \\
\text { with work achievement } \\
\text { 5. Compensation is relevant } \\
\text { with work risk }\end{array}$ \\
\hline
\end{tabular}


ISSN: 1410-4571, E-ISSN: 2541-2604

\begin{tabular}{|c|c|c|}
\hline Variable & Conceptual and Operational Definition & Indicators \\
\hline (1) & (3) & (4) \\
\hline \multirow{2}{*}{ Procedural justice } & $\begin{array}{l}\text { Conceptual: } \\
\text { Procedural justice is defined as justice } \\
\text { that is felt from the process and procedure } \\
\text { used to allocate decision (Kreitner and } \\
\text { Kinicki, 2003) }\end{array}$ & \multirow{2}{*}{$\begin{array}{l}\text { 1. Assessment of work } \\
\text { achievement consistent } \\
\text { with work realization } \\
\text { 2. Justice of work } \\
\text { achievement assessment } \\
\text { 3. Accuracy of work } \\
\text { achievement evaluation } \\
\text { 4. Errors in work } \\
\text { achievement assessment } \\
\text { 5. Justice in determining } \\
\text { position }\end{array}$} \\
\hline & $\begin{array}{l}\text { Operational: } \\
\text { Feeling or perception of justice felt by } \\
\text { the employees of BNI Branch Kebumen } \\
\text { against the system used to allocate } \\
\text { rewards for themselves }\end{array}$ & \\
\hline & $\begin{array}{l}\text { Job satisfaction is a person's attitude } \\
\text { towards their work. ( Ivancevich, 1987) }\end{array}$ & $\begin{array}{l}\text { 1. Compensation } \\
\text { 2. Promotion }\end{array}$ \\
\hline Job Satisfaction & $\begin{array}{l}\text { Operational: } \\
\text { Feeling conformity felt by the employees } \\
\text { of BNI Branch Kebumen with expectation } \\
\text { they work for the organization. }\end{array}$ & $\begin{array}{l}\text { 3. Superior supervision } \\
\text { 4. Co-workers relationship } \\
\text { 5. Interest in their job }\end{array}$ \\
\hline $\begin{array}{l}\text { Organizational } \\
\text { Citizenship } \\
\text { Behavior }\end{array}$ & $\begin{array}{l}\text { Conceptual: } \\
\text { OCB is formulated to describe employees' } \\
\text { interest in working more than usual and } \\
\text { exceeding the role they are responsible to } \\
\text { (Organ, 1988). } \\
\text { Operational: } \\
\text { Interest of the employees of BNI Branch } \\
\text { Kebumen to perform the job more than } \\
\text { they are expected to. }\end{array}$ & $\begin{array}{l}\text { 1. Altruism } \\
\text { 2. Conscientiousness } \\
\text { 3. Sportsmanship } \\
\text { 4. Courtesy } \\
\text { 5. Civic virtue }\end{array}$ \\
\hline
\end{tabular}

\section{Partial Least Square Analysis}

This research used Partial Least Square (PLS) to analyze data using SmartPLS software. PLS is structural equation modeling (SEM) based components or variance. According to Ghozali (2006), PLS is alternative approach that moves from SEM approach based covariance into variancebased. Covariance-based SEM generally test causality/theory, meanwhile PLS is predictive model. PLS is an powerful analysis method because it is not based on many assumptions (Ghozali, 2006). For example, data is not always normally distributed and sample should not always be big. Besides to confirm theory, PLS can also be used to clarify the correlation among laten variables. PLS can at once analyze construct formed with reflective and formative. It cannot be performed by covariance-based SEM because it will be unidentified model.

\section{RESULT OF THE RESEARCH AND DISCUSSION \\ Partial Least Square Analysis}

The calculation using smartPLS 2.0 generates the following result:

\section{Convergent Validity Test}

In convergent validity test, indicator that has correlation value less than 0,500 should be taken out of the model because it is considered to be unreliable and insignificant. After that, re-estimation to model will be carried out. The result of this research is that all indicators in the variable have two correlation values more than 0,500 so that it can be used as measurement tool. 


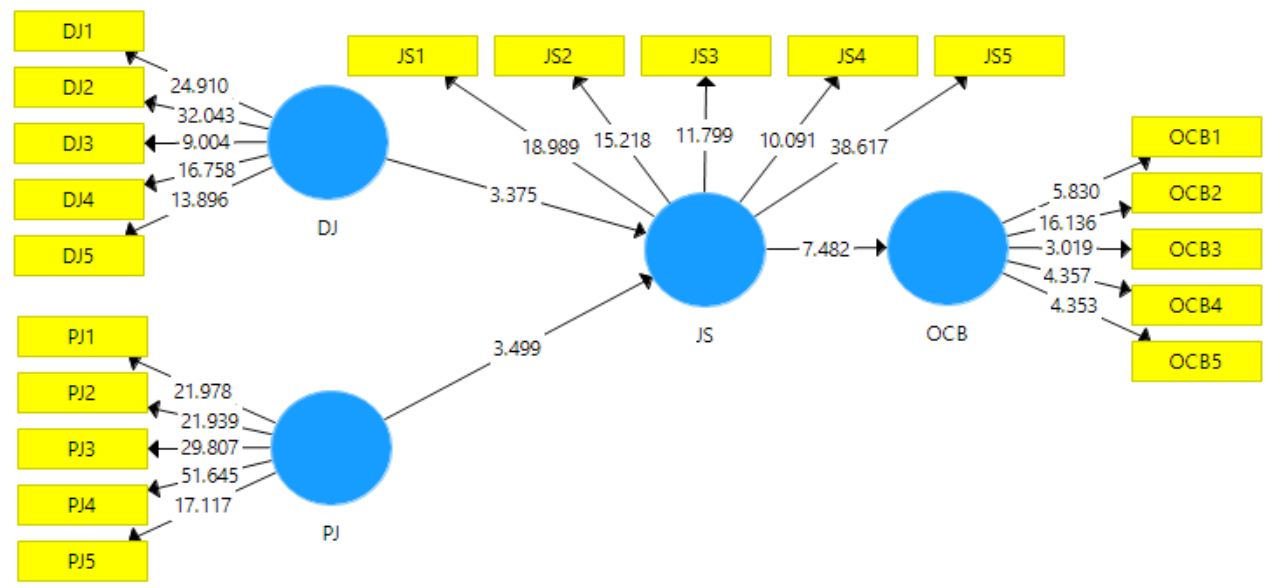

Figure 2 : Convergent Validity model

PJ: Procedural Justice; DJ: Distributive Justice; JS: Job Satisfaction;

OCB: Organizational Citizenship Behaviour

\section{Discriminant Validity Test}

Discriminant validity can be recognized by comparing square root of average variance extracted value of each variable with correlation coefficient value of other variables. Model is assumed to have sufficient discriminant validity, if square root of average variance extracted value is higher than correlation coefficient value among variables.

Table 2. Discriminant Validity Table

\begin{tabular}{ccccccc}
\hline & $\begin{array}{c}\text { Distr. } \\
\text { Just }\end{array}$ & $\begin{array}{c}\text { Proc. } \\
\text { Just }\end{array}$ & Job. Sat & OCB & $\begin{array}{c}\text { Average } \\
\text { variance } \\
\text { extracted } \\
\text { (AVE) }\end{array}$ & $\begin{array}{c}\text { Square } \\
\text { Root of } \\
\text { Average } \\
\text { Variance } \\
\text { Extracted }\end{array}$ \\
\hline Distr. Just & 1.000 & & & & 0.764 & 0.874 \\
Proc. Just & 0.719 & 1.000 & & & 0.750 & 0.866 \\
Job. Sat & 0.803 & 0.785 & 1.000 & & 0.721 & 0.849 \\
OCB & 0.308 & 0.544 & 0.544 & 1.000 & 0.624 & 0.790 \\
\hline
\end{tabular}

Based on the data on Table 2, it can be seen that square root of average variance extracted value of all variables are higher than correlation coefficient value among variables. Thus, it can be said that variable distributive justice has met discriminant validity.

\section{Composite Reliability Test}

Composite reliability test is done to test reliability of research variables. In addition, the result of composite reliability test can be seen in Table 3.

Table 3. The result of Composite Reliability Test

\begin{tabular}{cc}
\hline & Composite Reliability \\
\hline Distr. Just & 0.942 \\
Proc. Just & 0.937 \\
Job. Sat & 0.928 \\
OCB & 0.891 \\
\hline
\end{tabular}

Composite reliability test is said to be reliable if composite reliability value is higher than 0,700. Based on the data in Table 3, it can be seen that composite reliability value of variable distributive justice, procedural justice, job satisfaction and organizational citizenship behavior is higher than 0,700 . Thus, variable distributive justice, procedural justice, job satisfaction, and organizational citizenship behavior are reliable. 


\section{Structural Model Analysis}

Structural model analysis is performed by evaluating the estimation result of path coefficient parameter and its significance level. In addition, the result of significance test of path coefficient of each variable can be seen in Table 4.15.

Table 4. Parameter Coefficient and Statistical Values among Variables

\begin{tabular}{lcccc}
\hline & $\begin{array}{c}\text { original sample } \\
\text { estimate }\end{array}$ & $\begin{array}{c}\text { Mean of } \\
\text { subsamples }\end{array}$ & $\begin{array}{c}\text { Standard } \\
\text { deviation }\end{array}$ & T-Statistic \\
\hline Distr. Just -> Job. Sat & 0.493 & 0.477 & 0.146 & 3.375 \\
Proc. Just -> Job. Sat & 0.431 & 0.443 & 0.123 & 3.499 \\
Job. Sat -> OCB & 0.544 & 0.599 & 0.073 & 7.482 \\
\hline
\end{tabular}

\section{Hypothesis Testing}

Using significance level at $95 \%(\alpha=0,05)$ and degree of freedom $(n-k)$, the value of $t$ table is $\pm 2,001$.

\section{First Hypothesis Testing}

From the result of Partial Least Square analysis, the value of $t$ statistic of variable distributive justice on job satisfaction was 3,375; higher than $\mathrm{t}$ table. Thus, Ho was rejected and Ha was accepted which means that partially variable distributive justice had significant effect on job satisfaction and the first hypothesis which states that distributive justice had significant effect on job satisfaction, was accepted. The result of structural test generates the value of loading factor at 0,493 . This number is above 0,40 which shows that the effect of distributive justice on job satisfaction is significant. 49,3\% job satisfaction was meaningful for distributive justice while $50,7 \%$ was determined by other factors.

\section{Second Hypothesis Testing}

Based on the analysis result of Partial Least Square, the value of $t_{\text {statistic }}$ of variable procedural justice against job satisfaction was 3,499 , higher than that of $t_{\text {table }}$. Thus, Ho was rejected and $\mathrm{Ha}$ was accepted which means that partially variable procedural justice had significant effect on job satisfaction and the second hypothesis which states that procedural justice had significant effect on job satisfaction, was accepted. The result of structural test generates loading factor at 0,431 . This number is above 0,40 which shows that the effect of procedural justice on job satisfaction was significant. $43.1 \%$ of procedural justice factor was meaningful thing for job satisfaction while $56,9 \%$ was determined by other factors.

\section{Third Hypothesis Testing}

Based on the analysis result of Partial Least Square, the value of $t{ }_{\text {statistic }}$ of variable job satisfaction against organizational citizenship behavior was 7,482, higher than that of $\mathrm{t}$ table. Thus, Ho was rejected and $\mathrm{Ha}$ was accepted which means that partially variable job satisfaction had significant effect on organizational citizenship behavior and the third hypothesis which states that job satisfaction had significant effect to mediate between Distributive Justice and Procedural Justice on OCB, was accepted. The result of structural test generates loading factor at 0,544. This number is above 0,40 which shows that the effect of job satisfaction on organizational citizenship behavior was significant. $54.4 \%$ of job satisfaction factor was very meaningful for organizational citizenship behavior while $45,6 \%$ was determined by other factors.

\section{CONCLUSION,LIMITATION AND IMPLICATION}

\section{Conclusion}

Distributive justice had significant effect on working satisfaction at PT. Bank Negara Indonesia (Persero) Tbk. Branch Kebumen. It shows that the better the management of the company applies policies related to distributive justice, the more satisfied the employees of PT. Bank Negara Indonesia (Persero), Tbk. Branch Kebumen. The result of this research is consistent with the research conducted by Tremblay, et al (2000), which proves that there is significant causal relationship between Distributive justice and job satisfaction.

Procedural justice had significant effect on working satisfaction at PT. Bank Negara Indonesia (Persero) Tbk. Branch Kebumen. It 
shows that the better the management of the company applies policies related to procedural justice, the more satisfied the employees of PT. Bank Negara Indonesia (Persero), Tbk. Branch Kebumen. The result of this research is consistent with the research conducted by Alexander and Ruderman (1987), which proves that there is relationship between procedural and distributive justice factor and six variables of organization including working satisfaction.

Job satisfaction had significant effect to mediate between Distributive Justice and Procedural Justice on OCB at PT. Bank Negara Indonesia (Persero) Tbk. Branch Kebumen. It shows that the higher the job satisfaction of the employees, the higher the organizational citizenship behavior of the employees against the company. The result of this research is consistent with the research result (Bateman \& Organ, 1983; Smith, Organ \& Near, 1983; Organ, 1988b; Organ \& Ryan, 1995), which proves that there is consistency of positive relationship between job satisfaction and organizational citizenship behavior.

\section{Limitation}

As with any study, this study has some limitations that suggest areas for future research directions, Firstly, the results were derived from a cross-sectional research design, which cannot confirm the direction of causality among variables of this study. Secondly, limitations were related to the sample of this research, which was collected from one sector, the finance company sector, and only gathered from PT. Bank Negara Indonesia (persero), tbk.. Therefore, this setting may limit the generalizability of the study's finding.

In light of the above limitations of this study, there are some suggestions for future research. First, future research could look at the relationship between organizational justice and organizational citizenship behaviors, by using other mediators such as Organizational commitment, empowerment and participation in decision making. future research could also cover samples not only from finance industries but also from other company such as health industries, education industries and many more, as these could provide more meaningful results and could be generalized. Finally, it is suggested that future research should be conducted by using more population to be to be sampled.

\section{Implication}

As an effort in improving the employees' job satisfaction, the managers at PT. Bank Negara Indonesia (Persero) Tbk. Branch Kebumen should give more attention to polices related to the implementation of distributive justice and procedural justice. It can be done by giving reward, both financial and nonfinancial rewards, based on the contribution level of each employee against organization, job responsibility, level of education and training followed. Assessment of working achievement should be given properly both for permanent employees and contracted employees. Assessment procedure of working achievement should be done correctly and procedure of determining position should be done appropriately and equitably based on the criteria that are underlain on the values of work professionalism.

As an effort of optimizing the employees' organizational citizenship behavior, the managers of PT. Bank Negara Indonesia (Persero) Tbk. Branch Kebumen should notice the policies related to the improvement of job satisfaction to all employees by developing their positive value against organization on the fulfillment of all rights as employees and giving appreciation related to the accomplishment of their work activities.

\section{REFERENCES}

Abu Elanain, H. M. (2010a). Testing the direct and indirect relationship between organizational justice and work outcomes in a non-western context of the UAE. Journal of Management Development, Vol. 29, No. 1,pp 5-27

Alexander, S. and Ruderman, M. 1987. The Role of Procedural and Distribiutive Justice in Organizational Behavior. Social Justice Research. Vol 1, No. 2, pp. 177-198.

Azeem, S. M. (2010). Job satisfaction and organizational commitment among employees in the sultanate of Oman. Psychology, Vol. 1No. 4, pp 295-299. 
Baker, L.T. 2006. Promoting Ethical Behavior and Organizational Citizenship Behaviors: The Influence of Corporate Ethical Values Available at Journal of Business Research. Vol 59, pp. 849-857.

Bienstock, C.C., DeMoranville, C.W., dan Smith, R.K. 2003. Organizational Citizenship Behavior and Service Quality. Journal of Services Marketing, Vol 17 No. 4, pp. 357- 378.

Davis, E. \& Ward, E. (1995). Health benefits satisfaction in the public and private sectors: The role of distributive and procedural justice. Magazine: Public Personnel Management, Vol. 24, No. 3,pp 255-270

Diefendorff, J. M., Brown, D. J., Kamin, A. M., \& Lord, R. G. (2002). Examining The Roles of Job Involvement and Work Centrality in Predicting Organizational Citizenship Behaviors and Job Performance. Journal of Organizational Behavior, Vol. 23, pp. 93-108.

Folger, R. dan Konovsky, M.A. 1989. Effect of Procedural Justice and Distributive Justice on Reaction to Pays Raise Decisions. Academy of Management Journal. Vol. 32, No. 1, pp. 115-130.

Ghozali, Imam. 2006. Structural Equation Modeling Alternative Method with Partial Least Square (PLS). Badan Penerbit Universitas Diponegoro: Semarang.

Greenberg, J., \& Baron, R.A. (2008). Behavior in organizations (9th ed.). New Jersey: Prentice Hall.

Harif Amali Rifai. 2005. A Test of The Relationships Among Perceptions Of Justice, Job Satisfaction, Affective Commitment And Organizational Citizenship Behavior. Gadjah Mada International Journal of Business, May-August, Vol. 7, No. 2, pp. 131-154.

Ince, M., \& Gül, H. (2011). The effect of employees' perceptions of organizational justice on organizational citizenship behaviors: An application in Turkish public institutions. International Journal of Business and Management, Vol. 6, No. 6,pp 134-149.

Kreitner, Robert dan Kinicki, Angelo. 2003. Organisational Behaviour book one. Translation by Suandy. Jakarta: Salemba Empat.

Locke, A. E. 1976. The Nature and Causes of Job Satisfaction. Handbook of Industrial and Organizational Psychology. M. Dunnette. Chicago, Rand McNally : 1297-1350.

Martin, C. L., \& Bennett, N. (1996). The role of justice judgments in explaining the relationship between job satisfaction and organizational commitment. Group \& Organizational Management, Vol. 21, No. 1,pp 84-104.

Matheson, M. dan Ivancevich, J. 1987. Controlling Work Sress. Effective human Resource and Management Strategies. San Fransisco. Jossey-Bass.

Moorman, R. H. (1991). Relationship between organizational justice and organizational citizenship behaviors: does fairness perception influence employee citizenship? Journal of Applied Psychology, Vol. 76, No. 6, pp 845-855

Nadiri, H., \& Tanova C. (2010). An investigation of the role of justice in turnover intentions, job satisfaction, and organizational citizenship behaviors in hospitality industry. International Journal of Hospitality Management, Vol 29, pp 33-41.

Lambert, E., Hogan, N., Jiang, S., Elechi, O., Benjamin, B., Morris, A., \& Dupuy, P. (2010). The relationship among distributive and procedural justice and correctional life satisfaction, burnout, and turnover intent: An exploratory study. Journal of Criminal Justice, Vol 8, pp 7-16. 
Olkkonen, M. E., \& Lipponen, J. (2006). Relationships between organizational justice, identification with organization and work unit, and group-related outcomes. Organizational Behavior and Human Decision Processes, Vol 100, pp 202-215.

Organ, D. W. 1997. Organizational Citizenship Behavior: It's Construct Clean-up Time. Human Performance, 10, 85-97.

Organ, D. W. 1988. Organizational Citizenship Behavior: The Good Soldier Syndrome. Lexington, MA: Lexington Books.

Organ, D. W. 1998. Organizational Citizenship Behavior: The Good Soldier Syndrome. Lexington, MA: Lexington Books.

Organ D.W., Ryan K.K. 1995. A Meta-analytic Review of Attitudinal and Dispositional Predictors of Organizational Citizenship Behavior. Pers Psychol. Vol. 48, pp. 775-802.

Singarimbun, M. dan Soffian Effendi. 1995. Survey Research Method. Revised Edition Second Printing. Jakarta: LP3ES.

Sugiyono. 2003. Business Research Methods. Bandung: Alfabeta.

Pareke, F. Js., Bachri, S., \& Astuti, S. D. (2003). Kepuasan kerja sebagai variabel pemediasi pengaruh persepsi keadilan organisasional terhadap keinginan berpindah. Jurnal Bisnis dan Ekonomi. Vol. 10, No. 2, pp. 148-161

Podsakoff, P. M., Ahearne, M., \& MacKenzie, S. B. 1997. Organizational Citizenship Behavior and The Quantity and Quality of Work Group Performance. Journal of Applied Psychology. Vol.82. pp. 262-270.

Robbins, S.P. 2006. Organisational Behaviour Completed Edition. Jakarta: PT INDEKS GRAMEDIA Group.

Stephen P. Robbins, Timothy A. Judge. 2007. Organizational behavior — 15th ed. by Pearson Education, Inc., publishing as Prentice Hall

Tremblay, M., B. Sire \& D. Balkin. 2000. The Role of Organizational Justice in Pay and Employee Benefit Satisfaction, and its Effects on Work Attitudes. Group and Organization Management. Vol. 25, No. 3, pp. 269-290.

Umar, Husein. 2000. Human Resource Organization. Jakarta: Gramedia Pustaka Utama. 